\title{
EDITORIAL
}

\section{Annals Transitions}

Kurt C. Stange, MD, PbD, Editor; William R. Pbillips, MD, MPH, Senior Associate Editor

Ann Fam Med 2009;7:292. doi:10.1370/afm.1020.

$\mathrm{T}$

The growing number of submissions to the Annals and the life course of our editorial staff have resulted in a several transitions.

We are delighted to welcome Elizabeth Bayliss, MD, $\mathrm{MSPH}$, as a new associate editor. Dr Bayliss is a practicing family physician at Kaiser Permanente, Colorado, and clinician investigator at the Kaiser Permanente Institute for Health Research, as well as Assistant Clinical Professor of Family Medicine at the University of Colorado at Denver Health Sciences Center. Her research funded by the Agency for Healthcare Research and Quality involves patient-centered care, patient self-management, and assessing disease burden among people with multimorbidities, and she is a founding member of the International Research Community on Multimorbidity. A graduate of Harvard College and the University of Colorado, Dr Bayliss completed her residency in family medicine at Mercy Medical Center in Denver, Colorado, and was a National Research Service Award Primary Care Research Fellow at the University of Colorado.

We also are delighted to welcome Robert Ferrer, $\mathrm{MD}, \mathrm{MPH}$, as a new associate editor. Dr Ferrer is Associate Professor and Deputy Chair for Research in the Department of Family Medicine at the University of Texas Health Science Center at San Antonio. He is a family physician teaching full-scope family medicine at a practice that serves disadvantaged inner-city residents. His primary research interest is the effect of primary care on population health through such mechanisms as access, social determinants, and health behaviors. A graduate of Johns Hopkins University and the Hahnemann Medical College, Dr Ferrer completed his residency at Duke University, Durham, North Carolina, and was awarded a National Research Service Award Fellowship at the University of Washington, Seattle, Washington. From 2002 to 2006 he was a Robert Wood Johnson Foundation Generalist Physician Faculty Scholar.
Both Dr Bayliss and Dr Ferrer have excelled as volunteer reviewers for the Annals, and we look forward to their further contributions as editors.

Paul Nutting, MD, MSPH, who has brought great wisdom and experience to his role as an associate editor, will be transitioning to the role of consulting editor. We look forwarded to his continued contribution to the strategic direction of the Annals, and to his abiding involvement in important decisions, even as he moves to less day-to-day involvement.

William Miller, MD, MA, steps down as a consulting editor, a position he has held since the launch of the Annals. In this role he characterized the Annals publications from a variety of perspectives that reflect emerging trends in the field. ${ }^{1}$ This work helped launch the Annals Topics \& Themes feature described below. Dr Miller also helped to initiate the Annals Journal Club, which provides a template for residencies and others that wish to share learning from an article featured in each issue.

We are grateful to both Drs Nutting and Miller for their seminal contributions to the Annals formative years and look forward to their continued counsel.

The Topics \& Themes feature allows readers to view Annals publications by article type and by topics that represent important or emerging areas of interest. In addition, you can find relevant Annals content by using our search mechanism and by reading Annals supplements. It's all available at http://www. AnnFamMed.org.

To read or post commentaries in response to this article, see it online at http://www.annfammed.org/cgi/content/full/7/4/292.

\section{References}

1. Miller WL, Phillips WR, Acheson LS, et al. New knowledge for and about primary care: a view through the looking glass of the Annals of Family Medicine. Ann Fam Med. 2005; 3(3):197. http://www. annfammed.org/cgi/content/full/3/3/197. 